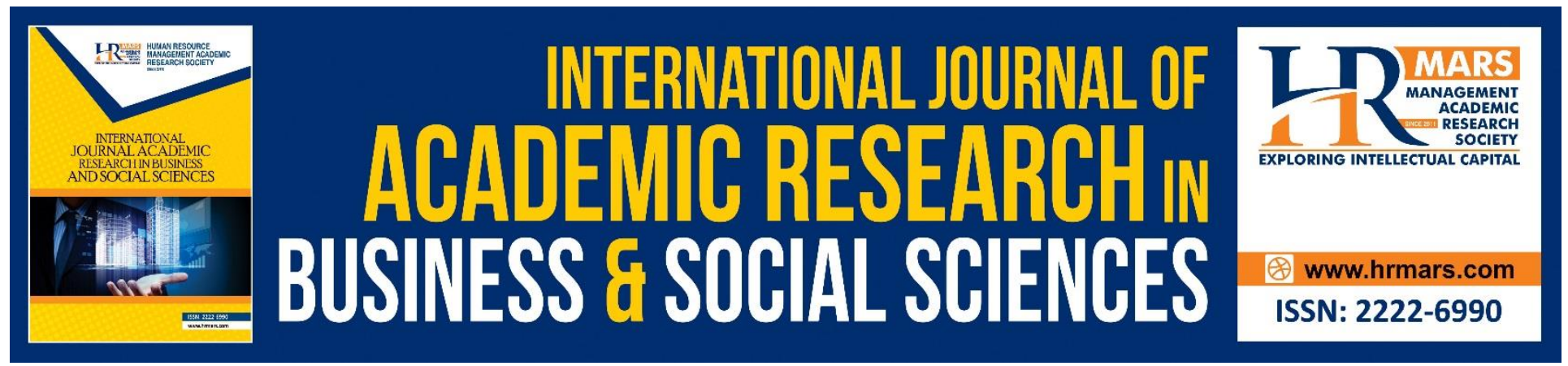

\title{
Determinants of Emotional Labour among Young Teachers
}

\author{
Jeffrey Lawrence D'Silva, Lau King Lang
}

To Link this Article: http://dx.doi.org/10.6007/IJARBSS/v10-i15/8240

DOI:10.6007/IJARBSS/v10-i15/8240

Received: 13 September 2020, Revised: 16 October 2020, Accepted: 14 November 2020

Published Online: 29 November 2020

In-Text Citation: (D'Silva \& Lang, 2020)

To Cite this Article: D’Silva, J. L., \& Lang, K. L. (2020). Determinants of Emotional Labour among Young Teachers. International Journal of Academic Research in Business and Social Sciences, 10(15), 142-163.

Copyright: (c) 2020 The Author(s)

Published by Human Resource Management Academic Research Society (www.hrmars.com)

This article is published under the Creative Commons Attribution (CC BY 4.0) license. Anyone may reproduce, distribute, translate and create derivative works of this article (for both commercial and non-commercial purposes), subject to full attribution to the original publication and authors. The full terms of this license may be seen

at: http://creativecommons.org/licences/by/4.0/legalcode

Special Issue: Youth and Community Wellbeing: Issues, Challenges and Opportunities for Empowerment V1, 2020, Pg. 142 - 163

Full Terms \& Conditions of access and use can be found at http://hrmars.com/index.php/pages/detail/publication-ethics 


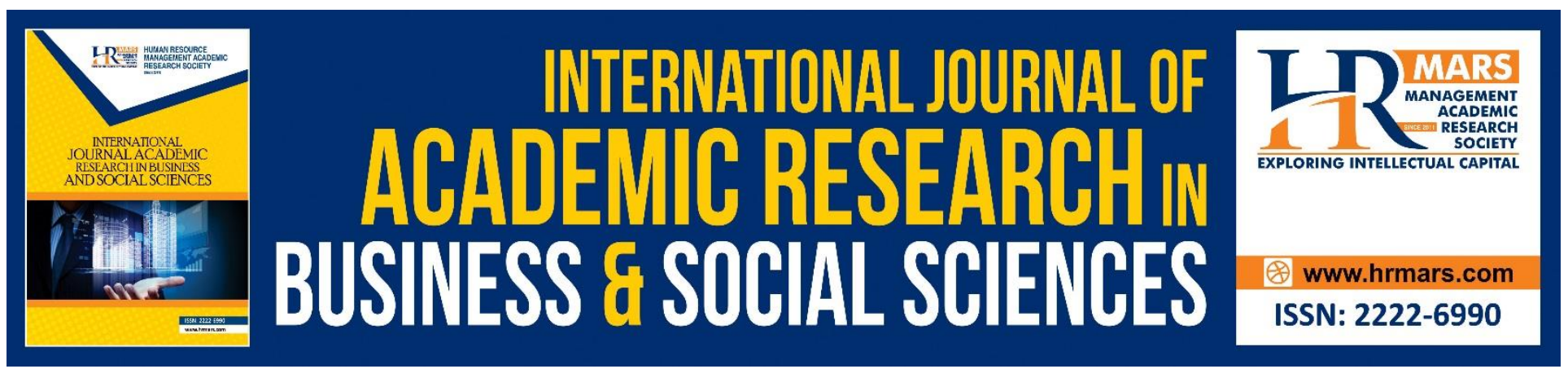

\title{
Determinants of Emotional Labour among Young Teachers
}

\author{
Jeffrey Lawrence D'Silva, Lau King Lang \\ Institute for Social Science Studies, Universiti Putra Malaysia, 43400 UPM Serdang, Selangor, \\ Malaysia \\ Email: jld@upm.edu.my, kinglang382@yahoo.co.uk
}

\begin{abstract}
Teachers are the main stakeholders in education and their emotional labour has a direct impact on the overall effectiveness of the school. The aim of this paper is to uncover the likely factors that will influence young teachers' emotional labour. A comprehensive review was conducted to obtain the data. A number of factors had been identified pertaining to organizational characteristics, job characteristics, personality traits, and spirituality characteristics that might influence emotional labour among young teachers. The review provides some guidance for future researchers to address the issues concerning emotional labour among young school educators.
\end{abstract}

Keywords: Emotional Labour, Organizational Characteristics, Personality Traits, Teachers, Effectiveness

\section{Introduction}

Undeniably, there have been many researches done on the phenomenon of emotional labour especially on the service industry (Lee et al., 2019). There are rapid changes in the structure of economy in service industry as well as in educational sector. These changes have led to employees under considerable amount of stress as they seek to meet the demands of their job. Thus there is an immense level of emotional labour. Teachers especially those who had just begun their teaching career are considered as professionals who are rated as high emotional workers (Ye \& Chen, 2015). They are the main stakeholders of developing the next generations of workforce who must not only be intellectually skilled but also the soft skills to succeed in the twenty-first century. In the school context teachers' representation of their emotion has great impact on the learners and their effectiveness as professionals. It is necessary to explore the emotional labour of teaching to promote the quality of education in schools (Buric \& Frenzel, 2020). As such it is important to understand the concept of emotional labour and its antecedents.

It is certain to say that emotions are a constant and indivisible part of being human. It plays a significant role both in individual's life as well as in the workplace (Korotaj \& Mrnjaus, 2020). A literature review on emotional labour from both the public and private sectors reveal that many 
INTERNATIONAL JOURNAL OF ACADEMIC RESEARCH IN BUSINESS AND SOCIAL SCIENCES

Vol. 10, No. 15, Youth and Community Wellbeing: Issues, Challenges and Opportunities for Empowerment V1. 2020, E-ISSN: $2222-6990$ ๑ 2020 HRMARS

research have been done on the phenomenon. Findings from initial literature review can be categorized under the following headings.

\section{Conceptualization and Definition of Emotional Labour}

The theory of emotional labour was first popularized by Hochschild in 1983. Tsang (2011) noted that her theory has its origin in the dramaturgical theory developed by Erving Goffman and Karl Marx's theory of alienation. Based on the dramaturgical theory, Hochschild conceived there are emotional rules which she labelled as feeling rules and expression rules. "The feeling rules specify the appropriate feeling in a given social setting" and "expression rules are guidance of the overt expression and display of the appropriate feeling in a given social setting." It simply means that all humans are actors and the world is the stage. In order to survive in the world's stage one need to manage their emotions and emotional display in an appropriate way. Hochschild's emotional management has two aspects: surface acting which is changing expression to change feelings; and deep acting that is changing feeling to change emotion expression. The emotional management in dramaturgical theory is known as emotion work.

Emotional management in Marxist's perspective is called emotional labour because in postindustrial societies (where Karl Marx's theory of alienation was built on) emotional management is no longer confined to private life but also work done for a wage. This happens especially in serviceoriented sectors where employees' emotion is used more for the benefit of a company. Hochschild (1983) used flight attendants in her research and concluded that smiling and warmth are the selling points of the airlines and thus employees are required by their employers to keep smiling and show warmth to customers. Its purpose is to evoke certain positive emotions in clients with the hope of achieving the objectives required by the company (mainly for its benefit).

Thus, emotional labour is defined as the "management of feeling to create a publicly observable facial and bodily display (Hochschild, 1983); emotional labour is sold for a wage and therefore has exchange value" (Choi \& Kim, 2015). Emotional labour understood here is the expression of expected emotions during work especially in service industry.

Since then efforts to refine the concept of emotional labour have been made by many researchers. In 1993, Ashforth and Humphrey describe emotional labour as "individual's management of emotional displays in order to actively portray socially and organizationally desired emotions during job-related interactions" (Lu \& Liou, 2015, p547). It emphasizes the actual behaviour rather than the presumed emotions underlying the behaviour.

Along similar frame of thought, Morris and Feldman (1996) explain that emotional labour is "the required efforts, plans and control for organizational emotion when interacting" (Hsu, 2012, p758). It is "an endeavour to exhibit emotions desired by the organization in a controlled manner for interpersonal interactions" (Ozan \& Sener, 2014, p111). Adding to the list is Grandey's (2000) definition from organizational perspective. It is taken as "affection regulation and emotional expressions for achieving organizational objectives" (Hsu, 2012, p758). Two years later, Zapf looks at emotional labour from the aspect of organization psychology and says it is about "the psychological regulation process for corresponding to organizational emotions" (Hsu, 2012, p758).

Thus emotional labour is an indispensable element in a professional role performed during professional duties. It requires control one's emotion so that his or her emotional states meet the demand by the organization or the job. In practice, emotional labour could mean suppression, hiding, 
INTERNATIONAL JOURNAL OF ACADEMIC RESEARCH IN BUSINESS AND SOCIAL SCIENCES

Vol. 10, No. 15, Youth and Community Wellbeing: Issues, Challenges and Opportunities for Empowerment V1. 2020, E-ISSN: 2222-6990 @) 2020 HRMARS

faking, or strengthening emotions. It could be understood as the degree of discord between the emotions that are actually felt and those that are required to be expressed in a job. In this context, emotional control could increases effectiveness and self-efficacy, facilitates an employee's selfexpression and strengthening his/her identification with the role they play in their workplace.

Brotheridge and Grandey (2002) introduced the term 'job-focused emotional labour' (referring to the perceived level of emotional requirements in an occupation) and 'employee-focused emotional labour' (focusing on the process of managing emotions and expression). These two perspectives are parallel to two psychosocial theories of work stress - Person-Environment Fit or Michigan Model and Demand-Control Support Model (Karasek et al., 1998). Byrne, Morton, and Dahling (2011) suggest using the process of emotional contagion to explain emotional labour in helping profession and public service. It is recognised that effective management of emotions has positive and instrumental values.

The debate on the nature of emotional labour is still on-going and no one specific definition gives a full picture. Lin (2009) tries to gel Hochschild's (1983) and Morris and Feldman's (1996) to explain the characteristics and degree of emotional labour with five dimensions to make the measurement of emotional labour more specific and complete. They are: basic emotional expression, the basic characteristics of emotional labour workers, that is presenting appropriate emotional state; surface emotional control which is workers' low-level control of personal emotion; deep emotional acting that impact on personal inner affection when conducting emotional tasks; emotional diversity - referring to workers presenting different emotional reactions according to distinct situations, customers, and people from various levels, or appearing more than one emotional state at work; interaction which refers to the frequency contacting with customers, period of interaction, and voiceto-voice contact with customers, such as the interactive time and frequency with customers

In a summary, the previous paragraphs have given an overview of the various definitions currently available in the literature around the concept of emotional labour. It is clear that there is clearly no agreement on the conceptual definition of emotional labour and the differences are mainly due to a matter of perspective. The main points from the preceding paragraph are: employees can and must regulate their emotional expressions at work for the organizational goals; and this regulation involves strategies to modify, create, and switch emotional expressions in the context of a paid job. While employees may be articulating what is appropriate and suitable for a particular job demand, faking and restraining may come with a cost because 'emotional labour' presents a problem for employers - how to deal with mismatched emotions between felt and expressed emotions of the employees?

Emotional labour represents the linear relationship between employees' true emotions and the required emotional displays by the profession. Thus emotion is so important and the success of an organization depends a lot on employees' emotions. It has become a commodity for organization's benefits. It fails to recognize that different people takes the challenges in their workplace differently and therefore act, respond, and behave differently. Therefore, emotional labour is not just about surface acting, deep acting, and natural emotions. There is more to emotional labour.

According to Brotheridge and Lee (2003); Grandey (2000), and Morris and Feldman (1996), the research on emotional labour up till now has been focusing on theoretical issues, construct validation, and the consequences of emotional labour. Although much has been said about emotional labour, there are still gaps in the literature. Further exploration or study could be done on what 
INTERNATIONAL JOURNAL OF ACADEMIC RESEARCH IN BUSINESS AND SOCIAL SCIENCES

Vol. 10, No. 15, Youth and Community Wellbeing: Issues, Challenges and Opportunities for Empowerment V1. 2020, E-ISSN: $2222-6990$ ๑ 2020 HRMARS

constitutes emotional labour; what are the determinants of emotional labour; what are the structures of emotional labour. There is a need to come to a common understanding on this issue. This is important because without a common structure it is difficult to discuss on the phenomenon of emotional demands, which has always been there but little investigation done to put the emotional labour of teaching in its rightful place.

There are gaps as to what is it that actually spurs the management and the act of appropriate bodily and facial emotional expression (Hochschild, 1983) and Ashforth and Humphrey (1993); what is it that motivates the efforts, planning and control needed to meet organizational display rules (Morris and Feldman, 1996); what is the 'unseen force' that drives the process of regulating emotions to meet the organizational objectives (Grandey, 2000); and what is spark that initiates the psychological regulating process to meet organizational emotions (Zapf, 2002).

Thus far, according to the author's knowledge, there was no comprehensive work dedicated to identify the predictive factors that have significant impact on emotional labour of young teachers.

\section{Emotion Work}

The term was introduced by Zapf, Vogt, Seifert, Mertini, and Isic (1999). They define emotion work as "the emotional requirements of a job, such as the requirement to express and handle negative emotions, the requirement to be sensitive to clients' emotions, and the requirement to show sympathy" (Naring, Vlerick, and Van de Ven, 2011, p4). How is this similar or different from emotional labour?

\section{Emotional Labour Strategies}

The essence of emotional labour is how employees show the expected emotions or behaviour at work. There are various strategies to describe how employees manage their emotions. The two common strategies suggested in the literature are surface acting and deep acting (Hochschild, 1983). Surface acting is the visual aspect of employees' emotion that corresponds with emotional display rules of an organization. It is about changing expression when dealing with clients - to appear and presenting signs of the required emotions without changing the employee's personal emotion.

On the other hand, deep acting involves creating externally appropriate emotion, and to change internal emotion according to emotional display principle of an organization. It involves changing of personal impression leading to modification of an emotional expression.

These two emotional management strategies are given a different name: superficial role play and deeply role play (Kruml and Geddes, 2000, as cited by Ozan and Sener, 2014). The third type is called intimate behaviours (Ashforth and Humphrey, 1993) which is also known as natural emotions (Kruml and Geddes, 2000). There could be a dichotomy within a teacher's emotion when emotional labour is about surface acting, deep acting, and natural emotions. But is there such a dichotomy in teachers or is it because past research may have just demonstrated the effects of prescriptive emotion management rather than emotional labour of teaching?

It seems that there is also disagreement in the model of emotional labour management strategies. This disagreement may be due to the conceptual level and operational level of emotional labour. To overcome this, Tolich (1993) suggests using the concepts of autonomous emotion management and regulated emotion management instead of surface acting, deep acting, and natural emotions. 
It would also lead to say that although past research on emotional display strategies is well established in the service and industry sectors, its effects on the emotional labour for use it educational settings, especially in the private international settings has not been extensively studied.

Another factor that influences emotional labour strategy is 'guanxi' as noted by Lu and Liou (2015, p549). 'Guanxi' is a concept to explain personal relationships and their development. It is defined as "personal closeness" and it has three components: trust (cognition-based); feelings (affect-based); and instrumental (Chen \& Peng, 2008). This concept is used to explain how co-workers relationships affect acquaintance, collaboration, and long-term exchange of reciprocal favours (Bedford, 2011). It also explains the significant variance of co-worker support, life satisfaction, and self-attributions for life success (Taormina \& Gao, 2010); mediates the relationship between affectivity and job satisfaction (Zhai, Lindorff, \& Cooper, 2013); mediates positive relationship between an employee's knowledge-sharing and innovative service behaviours (Hu, 2009). 'Guanxi' is a traditional Chinese concept to explain personal relationships which are either familial, acquaintance, or stranger. Using this to explain emotional labour is significant because the level of 'guanxi' affects the level and the consequences of emotional labour.

Indeed, at present, general research in emotional labour of teaching is still lacking. There is a need to explore further to understand Hochschild's emotional labour theory and its application in teaching profession. Operationally, would having a set of behavioural and affective expectations of teachers help in understand emotional labour of teaching? What would emotional labour of teaching be like when and if there is no dichotomy in teachers' life? Conceptually, instead of using concepts like use value, autonomous and regulated emotion management, how about looking at looking at emotional labour from the perspective of spirituality - meaning one's emotional display is neither surface acting nor deep acting but rather emotion expression of a transformed being where there is no separation between sacred and secular; where work is seen not as an end to itself; where work is seen as something with far-reaching impact on the next generation? Is it possible that emotional labour in teaching in school could lead to personal well-being, better professionalism, and positive work culture?

As far as the author is aware, there is no published analysis of the factors affecting the emotional labour strategies of the teachers in the private international school setting using different research method. A qualitative research on the emotional labour strategies may produce other strategies not known yet through quantitative study. It is presumed that human beings are complex, unique, as well as being vulnerable to their surroundings and therefore looking at their emotional labour strategies in such a narrow boundary does injustice to their humanity. There could be more to explore on how humans adapt and assimilate in their given environment.

\section{Consequences of Emotional Labour Strategies}

The common findings on surface acting are generally negative. Surface acting results in emotional dissonance which leads to employees' burnout, stress, overwhelming exhaustion, feeling of cynicism, detachment from job, a sense of ineffectiveness, lack of accomplishment, and withdrawal (Naring, Vlerick, \& Van de Ven, 2011); feeling alienated, poor job performance, and low commitment and enthusiasm (Tsang, 2011); anger, sadness, annoyance, emotional exhaustion, and depersonalization (Lu \& Liou, 2015). Other researches have also found similar negative effects of surface acting. 
The emotional strategy of deep acting results in more positive outcomes for both the employees and their organizations. Some of the positive effects are: job satisfaction, commitment, and effectiveness (Hargreaves, 1998b; Winograd, 2003; Isenbarger and Zembylas, 2006; Mack, 2008 - as cited by Tsang, 2011). It is said that using the concept of use-value as a type of emotional labour strategy may bring positive effects such as job commitment, job satisfaction, self-fulfilment, and professional identity of the employees (Hargreaves 1998b, 2000; Winograd, 2003; Zembylas, 2004a; Isenbarger and Zembylas, 2006; Hebson, et al., 2007; Mack, 2008; O’Connor 2008; Yuu, 2010 - as cited in Tsang, 2011).

In the reviewing the literature, some researchers used two factors, that is surface acting and deep acting. While others use three factors, that is surface acting, deep acting, and natural emotions. Zapf (2002) suggested that 'deliberate dissonance action' is also a kind of emotional labour strategy. This strategy exhibits itself in cases when "the requirements of emotional feelings are inconsistent with the requirements of emotional expression, for example, the organization require employee maintain inner neutral feeling and external positive behaviour" (Ye \& Chen, 2015).

The current research on the emotional labour strategies hinges on consequences of surface acting, deep acting, and the expression of naturally felt emotions. The deliberate dissonance action suggested by Zapf still needs further empirical research. Furthermore the emotional labour strategies come in combination and there is a lack of a combination of strategies in the current research on emotional labour strategy to better understand their consequences on the teachers.

\section{Emotional Display Rules}

Emotional display rules are basically which emotions have to be expressed or suppressed based on the expectation or the anticipation of organizational, occupational, and societal norms.

Studies on emotional rules are mainly for teachers and these rules may be implicit and disguised as teacher professionalism that constrained teachers' activities (Zembylas, 2002b, 2005) Winograd (2003) suggests five emotional rules of teaching. They are: [i] To love and to show enthusiasm for student; [ii] To be enthusiastic and passionate about subject matter; [iii] To avoid display of extreme emotions like anger, joy and sadness; [iv] To love their work; and [v] To have a sense of humour and laugh at their own mistakes and the peccadilloes of students.

The Chinese teachers in the Chinese context and culture have different emotional display rules. As pointed out by Yin and Lee (2012), these rules are classified into four points: teaching should be full of passion; hide negative emotions, maintain a positive emotional state; and instrumentalizing own emotions to achieve teaching goals.

It is further suggested by Chinese researchers that Chinese teachers' emotional display rules are influenced by socio-cultural background, educational practices, and organizational goals (Liu, 2012). Therefore, besides relating to students, these emotional display rules also encompass teacher's relationship with parents as well as teachers' relationship with school leaders.

It must be noted that there is no information on how these rules come about and whether there is consultation with teachers to have such rules. Therefore further research on designing emotional labour strategies or rules for teachers need to involve the main stakeholders of education - the teachers, for they are the workforce who needs to be reckoned with accordingly. Furthermore, it is also important to note that these rules may or may not be followed because what is truly felt and what teachers truly feel may not be what is expressed. 


\section{Organizational Characteristics}

The literature review showed the organizational characteristics had a great influence on emotional labour and these characteristics are the organizational life, organizational performance, and organizational commitment.

Organizational life consists of five aspects: organizational identity, rules of conduct which includes standard, corporate culture, organizational goals, and organizational citizenship. Employees are expected to demonstrate positive emotions in order to achieve organizational objectives. Factors contributing to achieving organizational goals are customer satisfaction, employees with high motivation, stress free environment, employees' strong emotional state and their commitment to the profession.

So much is expected of the employees for the sake of an organization's well-being and success. It would be beneficial to the employees for a research on the role of organizations in developing strong and positive emotions in their employees and assess how this will further enhance the profile of the company.

Organizational performance basically refers a measuring standard to evaluate organization's operational objectives. It has four dimensions as proposed by Gatewood and Felid (1998). They are firstly, production in which an organization evaluates the yield quantity, product or the service rendered. Second is the human resource where an organization evaluates employees' attendance and turnover rate. Third, is to evaluate the effectiveness of training given. Lastly, it is about using propositional index by the supervisors and leaders to evaluate employees' performance.

The third aspect of the organizational framework is organization commitment. It is about the degree of employees identifying themselves with the organization and the organization's objectives, and be part of the organization as a member (Hsu, 2012, p759). This is similar to organizational citizenship mentioned earlier. There are three types of organizational commitment mention in the literature. They are: continuous commitment to explain how employees continue to work for an organization; affective commitment seeks to see the strength of employees identifying themselves with the organizational objectives and values, and being willing to contribute in achieving these objectives; normative commitment is used to see the reasons why employees stay on in an organization.

However, there are still gaps in the views expressed in using organizational framework. The focus is mainly about the well-being of an organization at the expense of its employees' emotions. Emotional labour presents a dilemma for organization because in committing to the emotional labour display rules there arises a mismatch in employees' emotions. How can organizations assist to ensure that appropriate emotions are expressed while reducing the possible adverse outcomes? There is a lack of concern and research on how organization could do to foster positive emotional labour or training given to employees on how they could benefit from their emotional labour - physically, psychologically, as well as monetarily. Hence a research addressing these issues could herald positive working culture and climate into the workplace.

\section{Job Characteristics}

Past researches (Ashforth \& Humphrey, 1993; Morris \& Feldman, 1996; Diefendorff \& Richard, 2003; and Bono \& Vey, 2005) on emotional labour also reveal that emotional labour could be shaped by job situation. It can predict emotional labour through its display rules which are typically implicit and 
learnt through experience and socialization in a job environment. The type of display rules is firstly, the integrative display rules, which requires the expression of positive emotions and suppression of negative emotions (Byrne, Morton, \& Dahling, 2011). The second type is differentiating display rules which require the suppression of positive and expression of negative emotions. The third display rule is one which applies to 'masking occupations'. Those in these occupations are required to suppress both the positive and the negative emotions to project impartiality, calmness, and rationality.

Other factors contributing to emotional labour is job satisfaction and job characteristics. Job satisfaction refers to "an attitude or view of work itself and the related environment. It may involve employees' satisfaction with work status, work pattern, work stress, and interpersonal relationships in the workplace" (Jiang, Jiang, Park, 2013, p934). Job satisfaction is an emotional state caused by either good or bad emotional experiences at work (Smith \& Wakeley, 1972, as cited in Jiang, Jiang, and Park, 2013). But it could be a pleasant emotional state when there is good appraisal of one's job or good work experience (Locke, 1973, as cited by Jiang, Jiang, \& Park 2013).

There are two categories of job characteristics: the hygiene factor, relating to company policy and objective work conditions (job context); and the motivation factor or the job content which is relating to a sense of achievement and responsibility (Herzberg, Mausner, \& Snyderman, 1959), as cited in Jiang, Jiang, \& Park, 2013). Along similar topic, Turner and Lawrence, (1965, as cited in Jiang, Jiang, \& Park, 2013) identified five job characteristics that could influence employees' job satisfaction and performance. They are: skill diversity, job autonomy, selective social interaction, knowledge and skills, and responsibility. More recent research by Wright and Davis (2003) found four different job characteristics: job routines, job goal specificity, feedback, human resource development.

Although it is accepted of the effectiveness of looking at emotional labour from job characteristics, none have assessed on what is the role of the school authorities in positively elevating the role of emotional labour in teaching? How could these sections of the school take into consideration the 'cost' of emotional labour executed by teachers and reflect that in the form of remuneration for teachers? This is important because it is a way of recognition for the teachers - for the work they have done [both teaching and non-teaching responsibilities. Just as emotional labour comes with a cost on teachers; it is only fair that schools bear this 'cost'. There is also no research on determinants of emotional labour where job characteristics are being assessed together with other characteristics to determine the elements that spur emotional labour in a positive manner.

\section{Personality Traits}

Different people respond differently to the demands and stress in the workplace. Personality traits could provide a window for young teachers to understand and describe the phenomena of emotional labour. It could play a crucial role in determining emotional labour since it is a constant pattern, tendencies, characteristics that made up an individual's stable behaviour.

Funder (1997) suggests that personality may be portrayed as an individual's characteristic pattern of feeling or emotions, thoughts and behaviour. Likewise, Almlund et al. (2011) define personality as a tactic for responding to life situations. Together with them is Roberts (2009) who states personality as "the comparatively enduring patterns of feelings, thoughts, and behaviours that reflect the propensity to respond in certain ways under certain circumstances". 
The above definitions imply that personality has the ability to shape how an individual recognizes, interprets, and responds to external stimuli which may influence which emotions to express and which to suppress.

According to personality traits theory, individuals can be explained on the basis of certain traits. There are different models on personality traits but the most common model is the one presented by Costa and McCrae (1992, 1995). According to Naveed Yazdani (2013) their 'Big Five' model is based on the work of Raymond Cattell (1946). This model has five dimensions. They are: extraversion, neuroticism, agreeableness, conscientiousness and openness to experience. Each of these features is characterized by certain tendencies. Barrick and Mount (1991) as well as Prentice (2008) suggest that these dimensions give us a comprehensive classification to study individual differences.

The first dimension is extraversion. Extraverted people are usually expressive, energetic, assertive, sociable, active, talkative, and confident (Naveed, 2013). It is noted that these people tend to experience positive emotions.

The second dimension is neuroticism. Neurotic individuals are characterized as vulnerable, depressed, nervous, embarrassed, angry, insecure, and emotionally worried (Mroz \& Kaleta, 2016; McCrae \& Costa, 1985). These people are inclines to experience negative emotions.

The next dimension is agreeableness which is characterized by warmth, trust, cooperativeness, flexible, courteous, friendliness, soft-hearted, tolerant, and forgiving (Guilford \& Zimmerman, 1949, as cited by Naveed, 2013).

The fourth dimension is conscientiousness. The traits associated with this dimension are being well-organised, responsible, reliable, thorough, hardworking (Costa \& McCrae, 1980, 1991, 1995), persistent, and achievement oriented (Prentice, 2008).

The last dimension in the Big Five model on personality trait is openness to experience. Persons who are open to experiences are likely cultured, imaginative, original, curious, artistically sensitive, broad-minded and intelligent (Barrick \& Mount, 1991).

To date, there is no consensual classification on personality traits. But, Tokar et.al (1998) believe that the Big Five model is a useful framework to study emotional labour and there are others who had acknowledged the generalizability, comprehensiveness and robustness of the model (Goldberg, 1993; Wiggins \& Trapnell, 1997 - cited in Naveed, 2013).

Although this model is well established because of its generalizability, comprehensiveness, and robustness in looking at personality traits, it effects on the determinants of emotional labour for used in looking at the emotional labour of teachers has not been extensively studied. Therefore, it is sensible to modify the model in order to improve its usability to realise the full potential of the model to help to study the determinants of emotional labour amongst the teachers in a private international educational sector.

\section{Spirituality Characteristics}

Although not many research have been done on the influence of spiritual characteristics on emotional labour, the literature reviewed shows promising way ahead albeit with gaps for further investigation and study. 
The concept of spirituality is divided into pure and applied. According to Bosch (2009), pure spirituality refers to silent, unbounded and inner experience of pure self-awareness, and applied spirituality is about the practical application and measurable outcomes that automatically arise from inner experience of pure spirituality. This study focuses on applied spirituality.

Religions and spirituality are important components of many people's lives because to a certain extent they affect their feelings, inform their thoughts, and influence their behaviours both at work and at other times. Yet, these two are separate entities though connected somehow.

Moore and Casper (2006) viewed spirituality as some internal substance, a value, belief, attitude or emotion that affects a person's behaviour. Others describe it as spiritual intelligence (Emmons, 2000; Amram, 2007) where a person draws on to predict emotional functioning and adaptation. On the other hand, Synder et al. (2006) describe spirituality as a positive psychological concept. This concept encompasses love, compassion, patience, tolerance, forgiveness, contentment, personal responsibility, and a sense of harmony with one's environment.

Guillory (2000) takes an intrinsic-origin view of spirituality - meaning, spirituality is a concept or a principle that originates from the inside of an individual. So, spirituality is beyond programmed beliefs and values (Devi, 2016). Along the same line of thought, Brandt (1996 - cited in Krihnakumar \& Neck, 2002) proposes that the goal of spirituality is greater personal awareness of universal values, helping an individual live and work better and more joyfully. He further asserts that spirituality is void of the formal and ceremonial connotations of religion. It is non-denominational, non-hierarchical, and non-ecclesiastical. It is mankind's inner search for meaning and fulfilment regardless of religion.

The expression of spirituality can be seen through facets such as team work, job engagement, job satisfaction, turnover, and a sense of mental, emotional, and spiritual connections. There is growing evidence that spirituality results in positive outcomes in the workplace. Gull and Doh (2004 - cited in Devi, 2016) suggest spirituality makes employees more engaged and they work more responsibly, ethically, collaboratively and creatively. Furthermore, it is believed that spirituality in the workplace lead to intuition, honesty and trust, personal fulfilment, commitment, and organizational performance (Krishnakumar \& Neck, 2002).

Bryne, Morton, and Dahling (2011) suggest that these entities could affect emotional labour positively because of what exist in their sacred texts. The team of researchers assumed that tenets such as charity, helping others, provide support, establish meaning, optimistic orientation to life, empathy, compassion, sincere concerns for others, and communal spirit enshrined in the sacred texts could lead to adherents having positive emotions that they could bring to the work environment.

Furthermore, it is suggested that religious and spiritual people experience fewer detrimental outcomes from emotional labour because they have effective coping mechanisms - communal support and strong faith and the requirement from their religions to forgive. Being able to forgive then will lead to healthier emotional labour at workplaces.

Indeed, at present, general research in the correlation of spirituality and emotional labour is still in its infancy. As far as the author is aware, there is no comprehensive work dedicated to investigate the determinants of emotional labour amongst the teachers in the private international school context, using spirituality as the main variable or in combination with other frameworks to look at the predictors of emotional labour. There is also no published analysis of the factor affecting emotional labour of teachers using longitudinal research method. 
Related to the spirituality framework is the concept of spiritual work. This construct is relatively new and it is used to refer to the commodification and regulation of spirituality in organizational settings. This could mean that spirituality will play a greater role in predicting or determining emotional labour.

\section{Conclusion}

So much has been researched on the emotional labour and other variables. However little work has been carried out to investigate on the determinants amongst young teachers in public and private settings and previous works have not comprehensively covered these group of teachers. Neither has previous research study on the predictors of emotional labours among the young teachers in these schools.

There is still much to explore on emotional labour. The initial literature review suggests many gaps that need to be filled in future research. One main area that calls for attention is: What determines emotional labour? The issue is what the factor that propels that effort is, affect that planning and decision making? What is the 'unseen force' in the person that spurs or controls the control needed? What is the key that regulate the process of regulating? What drives the quality of emotional labour in school? What is behind all surface acting and deep acting (which are internal management of emotions), frequency, duration, and emotional dissonance? What is that something 'unseen yet all-encompassing and all-embracing power' that gave the impetus?

Till today, there are only a couple of published analysis on the factors affecting emotional labour of young teachers using a combination of antecedents to investigate emotional labour. Therefore, it is sensible to modify the work done previously in order to improve the study of emotional labour of teaching and teachers in order to realize the full potential of emotional labour benefitting both the teachers and the academia.

\section{References}

Abelson, R. P. (1985). A variance explanation paradox: When a little is a lot. Psychological Bulletin 97(1), 129-133. Retrieved from http://citeseerx.ist.psu.edu/viewdoc/download?doi=10.1.1. 318.6983\&rep=rep1\&type $=p d f$

Almlund, M., Duckworth, A. L., Heckman, J. J., \& Kautz, T. D. (2011) Personality psychology and economics. National Bureau of Economic Research. Retrieved from http://ftp.iza.org/dp5500. pdf

Amram, Y. (2007). What is spiritual intelligences? An ecumenical, grounded theory. Working paper of the Institute of Transpersonal Psychology. CA. Retrieved from http://www.yosiamram.net/docs /what_is_SI_Amram_wrkg_paper.pdf

Andersen, L. B. (2011). Teacher diversity: Do male and female teachers have different self-efficacy and job satisfaction? Retrieved from https://soc.kuleuven.be/io/egpa/HRM/bucharest/Ander sen2011.pdf

Ang, M. C. H., \& Amin, H. (2016). Why work emotions at work matters: Examining the influence of emotional labour and emotional intelligence on workplace behaviours among service workers in East Malaysia. Kajian Malaysian, 34(1), 79-105. Retrieved from http://web.usm.my/km/ 34(1)2016/km34012016_04.pdf 
INTERNATIONAL JOURNAL OF ACADEMIC RESEARCH IN BUSINESS AND SOCIAL SCIENCES

Vol. 10, No. 15, Youth and Community Wellbeing: Issues, Challenges and Opportunities for Empowerment V1. 2020, E-ISSN: 2222-6990 @) 2020 HRMARS

Ashforth, B. E., \& Humphrey, R. H. (1993). Emotional labor in service roles: The influence of identity. Academy of Management Review, 18, 88-115. Retrieved from http://doi.org/df4qpz

Banks, R. C. (2009). Caring teachers and their impact: A phenomological study of students' perception. Doctoral dissertation. College of Education, Washington State University. Retrieved from http://www.dissertations.wsu.edu/Dissertations/Spring2009/r_banks_041309.pdf

Barrick, M. R., \& Mount, M. K. (1991). The big five personality dimensions and job performance: a meta-analysis. Personality Psychology 44(1), 1-26. Retrieved from http://www.sitesbysarah. com/mbwp/Pubs/1991_Barrick_Mount.pdf

Baumeister, R. F., Heatherton, T. F., \& Tice, D. M. (1994). Losing control: How and why people fall at self-regulation. San Diego, CA: Academic Press. Retrieved from http://courses.ucsd.edu/gkoob /PSYCH188/188_Losing_Control.pdf

Bedford, O. (2011). Guanxi-building in the workplace: A dynamic process model of working and backdoor guanxi. Journal of Business Ethics, 104, 149-158. http://doi.org/cvgjsj

Bono, J. E., \& Vey, M. A. (2005). Toward understanding emotional management at work: a quantitative review of emotional labor research. In: C.E.J. Hartel, W.J. Zerbe, and N.M. Ashkanasy. (ed.). Emotions in organizational behaviour. Mahwah, NJ: LEA Publishers, 213-233. Retrieved from: file:///C:/My\%20Documents2/oum\%20project\%20paper\%202017/ interpreting\%20ssps\%20analysis/discussion\%20and\%20implication\%20and\%20recommendati on/ashkanasybook-emolabwell-being.pdf

Bosch, L. (2009). The inevitable role of spirituality in the workplace. Business Intelligence Journal, 2(1), 139-157. Retrieved from http://citeseerx.ist.psu.edu/viewdoc/download?doi=10.1.1.462. 7166\&rep=rep1\&type $=$ pdf

Brandt, E. (1996). Corporate pioneers explore spirituality. HR Magazine, 41, 82-97.

Brotheridge, C. M., \& Grandey, A. A. (2002). Emotional Labor and Burnout: Comparing Two Perspectives of "People Work". Journal of Vocational Behaviour, 60(1), 17-39. Retrieved from: http://www.sciencedirect.com/science/article/pii/S0001879101918159

Brotheridge, C. M., \& Lee, R. T. (2003), Development and validation of the Emotional Labour Scale. Journal of Occupational and Organizational Psychology, 76, 365-379. Retrieved from doi:10.1348/096317903769647229

Brown, E. L. (2011). Emotion matters: Exploring the emotional labor of teaching. Unpublished doctoral dissertation. University of Pittsburgh. Retrieved from https://core.ac.uk/ download/pdf/12207032.pdf

Buric, I., \& Frenzel, A. C. (2020). Teacher emotional labour, instructional strategies and students' academic engagement: a multilevel analysis, Teachers and Teaching, DOI: 10.1080/13540602.2020.1740194

Burke, P. J. (1991). Identity processes and social stress. American Sociological Review, 56, 836-849. Retrieved from http://rsp-lab11.ucr.edu/Papers/91.pdf

Burke, P. J. (1996). Social identities and psychological stress: Perspectives on structures, theory, life course, and methods. ed. H.B. Kaplan, pp141-147. Orlando, FL: Academy Press.

Byrne, C. J., Morton, D. M., \& Dahling, J. J. (2011). Spirituality, religion, and emotional labour in the workplace. Journal of Management, Spirituality \& Religion, 8(4), 299-315. Retrieved from http://dx.doi.org/10.1080/14766086.2011.630169 
INTERNATIONAL JOURNAL OF ACADEMIC RESEARCH IN BUSINESS AND SOCIAL SCIENCES

Vol. 10, No. 15, Youth and Community Wellbeing: Issues, Challenges and Opportunities for Empowerment V1. 2020, E-ISSN: 2222-6990 @) 2020 HRMARS

Chen, X. P., \& Peng, S. (2008). Guanxi dynamics: Shift in the closeness of ties between Chinese coworkers. Management and Organization Review, 4, 63-80. Retrieved from http://doi.org/b2hjww

Cheung, Y. L., \& Lun, M. C. (2015). Relation between emotional labor and organizational citizenship behaviour: An investigation among Chinese teaching professionals. The Journal of General Psychology, 142(4), 253-272. Retrieved from http://dx.doi.org/10.1080/00221309.2015.1091 764

Choi, Y. G., \& Kim, K. S. (2015). A Literature Review of Emotional Labor and Emotional Labor Strategies. Universal Journal of Management, 3(7), 283-290. Retrieved from http://www. hrpub.org/download/20150730/UJM4-12104187.pdf

Chu, K. H. (2002). The effects of emotional labor on employee work outcomes. Unpublished PhD dissertation. The Faculty of the Virginia Polytechnic Institute and State University, Blacksburg, Virginia, USA.

Collins, R. (2004). Interaction ritual chains. Princeton, NJ: Princeton University Press. Retrieved from http://www.wunderkim.com/Collins-Interaction-Ritual-Chains.pdf

Costa, P. T., \& McCrae, R. R. (1980).Influence of extraversion and neuroticism on subjective wellbeing: Happy and unhappy people. Journal of Personality and Social Psychology. 38(4), 668-678. Retrieved from https://www.researchgate.net/publication/15816781_Costa_Jr_PT_Mc Crae_RR_Influence_of_extraversion_neuroticism_on_subjective_wellbeing_happy_unhappy_ people_J_Pers_Soc_Psychol_38_668-678

Costa, P. T. Jr., \& McCrae, R. R. (1992). A contemplated revision of the NEO Five-Factor Inventory. Personality and Individual Differences, 36 (2004), 587-596. Retrieved from http://cda.psych.uiuc.edu/multivariate_fall_2013/neo_mccrae_costa.pdf

Costa, P. T. Jr., \& McCrae, R. R. (1995). Domains and Facets: Hierarchical Personality Assessment Using the Revised NEO Personality Inventory. Journal of Personality Assessment, 64(1), 21-50 http://jenni.uchicago.edu/econ-psych-traits/CostaMcCrae1995.pdf

Creating effective teaching and learning environment (2009). First results from TALIS. OECD. Retrieved from http://www.oecd.org/berlin/43541664.pdf

Dahling, J. J., \& Perez, L. A. (2010). Older worker, different actor? Linking age and emotional labor strategies. Personality and Individual Differences, 48, 574-578. Retrieved from: https://dahling.pages.tcnj.edu/files/2013/06/Dahling-Perez-2010.pdf

Devi, B. R. (2016). A study on human resource perspectives on emotional labour in service sector. IOSR Journal of Business and Management, 18(9), 154-158. Retrieved from http://www.iosrjournals.org/iosr-jbm/papers/Vol18-issue9/Version-2/U180902154158.pdf

Devi, S. (2016). Impact of spirituality and emotional intelligence on employee engagement. International Journal of Applied Research, 2(4), 321-325. Retrieved from http://www.allresearchjournal.com/archives/2016/vol2issue4/PartE/2-3-11.pdf

Diefendorff, J. M., Croyle, M. H., \& Gosserand, R. H. (2005). The dimensionality and antecedents of emotional labor strategies. Journal of Vocational Behavior, 66, 339-357. Retrieved from http://doi.org/czn

Diefendorff, J. M., \& Richard, E. (2003). Antecedents and consequences of emotional display rule perceptions. Journal of Applied Psychology, 88, 284-294. Retrieved from http://psycnet.apa. org/doi/10.1037/0021-9010.88.2.284 
INTERNATIONAL JOURNAL OF ACADEMIC RESEARCH IN BUSINESS AND SOCIAL SCIENCES

Vol. 10, No. 15, Youth and Community Wellbeing: Issues, Challenges and Opportunities for Empowerment V1. 2020, E-ISSN: 2222-6990 @ 2020 HRMARS

Durkheim, E. (1965). The elementary forms of the religious life. New York: Free Press. Retrieved from http://bookengine.site/go/read.php?id=B01182NZJQ

Emmons, R. A. (2000). Is spirituality an intelligence? The International Journal for the Psychology of Religion, 10 (1), 1-26. Retrieved from http://dx.doi.org/10.1207/S15327582IJPR1001_2

Eroglu, E. (2010). Effects of organizational communication on the management of the labors' expressing their emotions. Selcuk Universitesi lletisim Fakultesi Akademik Dergisi, 6, 18-33.

Falk, R. F., \& Miller, N. B. (1992). A primer of soft modeling. Akron, OH: University of Akron Press. Retrieved from https://www.researchgate.net/publication/232590534_A_Primer_for_Soft_ Modeling

Funder, D. C. (1997). The personality puzzle. $6^{\text {th }}$ ed. WW Norton \& Co. Retrieved from https://www.scribd.com/document/339522795/The-Personality-Puzzle-by-David-Funder-6thEdition-pdf

Gatewood, R. D. \& Felid, H. S. (1998). Human resource selection (4 ${ }^{\text {th }}$ ed.). Fort Worth, TX: The Dryden Press.

Goffman, E. (1959). The presentation of self in everyday life. University of Edinburgh: Social Science Research Centre. Retrieved from: https://monoskop.org/images/1/19/Goffman_Erving_The _Presentation_of_Self_in_Everyday_Life.pdf

Goldberg, L. R. (1993). The structure of phenotypic personality traits. American Pscychologist, 48(1), 26. Retrieved from http://projects.ori.org//rg/PDFs_papers/Goldberg.Am.Psych.1993.pdf

Gull, G. A., \& Doh, J. (2004). The transmutation of the organization: Toward a more spiritual workplace. Journal of Management Inquiry, 13(2), 128-135. Retrieved from http://ejournal.narotama.ac.id/files/the\%20transmutation\%20of\%20the\%20organization\%20 toward\%20a\%20more\%20spiritual\%20workplace.pdf

Guillory, W. A. (2000). The living organization: Spirituality in the workplace. Innovations International Inc. UT: Salt Lake City.

Grandey, A. A. (2000). Emotional regulation in the workplace: A new way to conceptualize emotional labor. Journal of Occupational Health Psychology, 5, 95-110. Retrieved from http://doi.org/fhfzhc

Grandey, A. A. (2003). When "the show must go on": Surface acting and deep acting as determinants of emotional exhaustions and peer-rated service delivery. Academy of Management Journal, 46, 86-96. Retrieved from http://doi.org/cbz6gz

Greenberg, J. (1998). Managing behavior in organizations science in service to practice. Upper Saddle River, NJ: Prentice-Hall Inc.

Gross, J. J. (1998). The emerging field of emotion regulation: An integrative review. Review of General Psychology, 2(3), 271-299. Retrieved from https://courses.washington.edu/dbt560 /GrossRev.pdf

Hall, T. W., \& Edwards, K. J. (2002). The spiritual assessment inventory: A theistic model and measure for assessing spiritual development. Journal for the Scientific Study of Religion, 41(2), 341-357. Retrieve from http://130.18.86.27/faculty/warkentin/SecurityPapers/Merrill/Hall Edwards2002_JSSR41_2_TheisticModelMeasureAssessSpiritualDevelopment.pdf

Hargreaves, A. (1988b). The emotional practice of teaching. Teaching and Teacher Education, 14(8), 835-854. Retrieved from https://doi.org/10.1016/S0742-051X(98)00025-0 
INTERNATIONAL JOURNAL OF ACADEMIC RESEARCH IN BUSINESS AND SOCIAL SCIENCES

Vol. 10, No. 15, Youth and Community Wellbeing: Issues, Challenges and Opportunities for Empowerment V1. 2020, E-ISSN: 2222-6990 @ 2020 HRMARS

Hargreaves, A. (2000). Mixed emotions: Teachers' perceptions of their interactions with students. Teaching and Teacher Education, 16, 811-826. Retrieved from https://doi.org/10.1016/S0742051X(00)00028-7

Hardt, J., Schultz, S., Xander, C., Becker, G., \& Dragan, M. (2012) The spirituality questionnaire: Core dimensions of spirituality. Scientific Research, 3(1), 116-122. Retrieved from http://dx.doi. org/10.4236/psych.2012.31017

Hebson, G., Earnshaw, J., \& Marchington, L. (2007). Too emotional to be capable? The changing nature of emotion work in definitions of 'capable teaching'. Journal of Educational Policy, 22(6), 675-694. Retrieved from http://dx.doi.org/10.1080/02680930701625312

Hernandez, B. C. (2011). The religiosity and spirituality scale for youth development and initial validation. A Dissertation. Retrieved from http://digitalcommons.Isu.edu/cgi/viewcontent.cgi? article $=3205 \&$ context $=$ gradschool_dissertations.

Herzberg, F., Mausner, B., \& Syndermann, B. B. (1959). The motivation to work (2 ${ }^{\text {nd }}$ ed.). New York: Wiley.

Hochschild, A. R. (1983). The managed heart: Commercialization of human feeling. Berkeley, CA: University of California Press.

Lan, H. J. [2012]. Effects of emotional labor on organizational performance in service industry. Pakistan Journal of Statistics, 28(5), 757-765. Retrieved from http://eds.b.ebscohost.com. newdc.oum.edu.my/eds/pdfviewer/pdfviewer?sid=b9cddfad-a5c0-4c59-8d24cbe2a3fb2aeb\% 40sessionmgr102\&vid=0\&hid=117

$\mathrm{Hu}$, M. L. (2009). Knowledge sharing and innovative service behavior relationship: Guanxi as mediator. Social Behavior and Personality: An International Journal, 37, 977-992. Retrieved from http://doi.org/2gb

Isenbarger, L., \& Zembylas, M. (2006). The emotional labour of caring in teaching. Teaching and Teacher Education, 22(1), 120-134. Retrieved from http://doi:10.1016/j.tate.2005.07.002

Jiang, X., Jiang, Z., \& Park, D. S. [2013]. Emotional Labor Strategy and Job Satisfaction: A Chinese Perspective. Social Behavior and Personality, 41(6), 933-938. Retrieved from http://eds.b.ebscohost.com.newdc.oum.edu.my/eds/pdfviewer/pdfviewer?sid=a59e0addff58-492e-9bf4-88c207e97260\%40sessionmgr101\&vid=0\&hid=117

Johnson, H. M., \& Spector, P. E. (2007). Service with a smile: Do emotional intelligence, gender, and autonomy moderate the emotional labor process? Journal of Occupational Health Psychology, 12, 319-333.

Joseph, D. L., \& Newman, D. A. (2010). Emotional intelligence: An integrative meta-analysis and cascading model. Journal of Applied Psychology, 95, 54-78. Retrieved from: http://dx.doi.org/10.1037/a0017286

Karasek, R., Brisson, C., Kawakami, N., Houtman, I., Bongers, P., \& Amick, B. (1998). The job content questionnaire (JCQ): An instrument for internationally comparative assessments of psychosocial job characteristics. Journal of Occupational Health Psychology, 3(4), 322-355. Retrieved from http://citeseerx.ist.psu.edu/viewdoc/download?doi=10.1.1.515.1283\&rep=rep 1\&type=pdf

Kaya, O., \& Ozhan, C., K. (2012). Emotional labour and burnout relationship: A research on tourist guides. Calisma Iliskileri Dergisi, 3, 109-130. 
INTERNATIONAL JOURNAL OF ACADEMIC RESEARCH IN BUSINESS AND SOCIAL SCIENCES

Vol. 10, No. 15, Youth and Community Wellbeing: Issues, Challenges and Opportunities for Empowerment V1. 2020, E-ISSN: 2222-6990 @) 2020 HRMARS

Korotaj, B. V., \& Mrnjaus, K. (2020). Emotional competence: a prerequisite for effective teaching, Economic Research-Ekonomska Istraživanja, DOI: 10.1080/1331677X.2020.1751673

Krishnakumar, S., \& Neck, C. P. (2002). The what, why and how of spirituality in the workplace. Journal of Managerial Psychology, 17, 153-164. Retrieved from https://www.researchgate.net/ profile/Christopher_Neck/publication/242341520_The_What_Why_and_How_of_spirituality _in_the_workplace/links/00b7d53c76341aad97000000/The-What-Why-and-How-ofspirituality-in-the-workplace.pdf

Kruml, S. M., \& Geddes, D. (2000). Exploring the dimensions of emotional labor: The heart of Hochschild's work. Management Communication Quarterly, 14, 8-49. Retrieved from https:// www.researchgate.net/publication/247741875_Exploring_the_Dimensions_of_Emotional_La bor_The_Heart_of_Hochschild\%27s_Work

Lawler, E. J. (2001). An affect theory of social exchange. American Journal of Sociology. 107, 321-352. Retrieved from http://digitalcommons.ilr.cornell.edu/cgi/viewcontent.cgi?article=1661\&cont ext=articles

Lazanyi, K. (2010). Organizational consequences of emotional labour in management. PhD Summaries. Applied Studies in Agribusiness and Commerce - APSTRACT. Retreived from https://ageconsearch.umn.edu/bitstream/104684/2/21_Lazanyi_Organozational_Apstract_j. pdf

Lazarus, R. S. (1991). Emotion and adaptation. New York: Oxford University Press.

Lee, Y. H., Lee, S. H. B., \& Chung, J. Y. (2019). Research on How Emotional Expressions of Emotional Labor Workers and Perception of Customer Feedbacks Affect Turnover Intentions: Emphasis on Moderating Effects of Emotional Intelligence. Frontiers in Psychology, 9, 1-21. https://doi.org/10.3389/fpsyg.2018.02526

Lin, S. P. (2009). A study of the development of emotional labor loading scale. Sun Yat-Sen Management Review, 3(8), 417-447.

Liu, Y. C. (2012). Discussion on Teachers' Emotional Display Rules. Journal of Zhejiang Normal University: Social Sciences, 63, 6-11.

Liu, Y., \& Zhang, D. (2015). Development of questionnaire on emotional labor among primary and secondary school teachers. Journal of Education and Training Studies, 3(1), 46-55. Retrieved from http://dx.doi.org/10.11114/jets.v3il.551

Locke, E. A. (1973). Satisfiers and dissatisfiers among white-collar and blue-collar employees. Journal of Applied Psychology, 58, 67-76. Retrieved from http://doi.org/cpzevk

Lu, H. P., \& Liou, H. R. [2015]. Emotional labor and workplace relationships among personnel officials and teachers. Society for Personality Research : Social Behavior and Personality, 43(4), $547-$ 558. Retrieved from http://eds.b.ebscohost.com.newdc.oum.edu.my/eds/pdfviewer/pdf viewer?sid=b568f0a6-f234-43d9-99ce-0c62a807aeb1\%40sessionmgr103\&vid=1\&hid=117

Mack, N. (2008). Energy and enthusiasm: Don't start the school year without them. English Journal, 98(10), 18-25.

Maslow hierarchy of needs. Retrieve from https://www.google.com/imgres?imgurl=https://www. simplypsychology.org/maslow.jpg\&imgrefurl=https://www.simplypsychology.org/maslow.ht $\mathrm{ml} \& \mathrm{~h}=1000 \& \mathrm{w}=1344 \& \mathrm{tbnid}=\mathrm{fNoXBWqbfhd}-$

UM:\&tbnh=157\&tbnw=211\&usg=_rSxdSGQrFRKjz 
INTERNATIONAL JOURNAL OF ACADEMIC RESEARCH IN BUSINESS AND SOCIAL SCIENCES

Vol. 10, No. 15, Youth and Community Wellbeing: Issues, Challenges and Opportunities for Empowerment V1. 2020, E-ISSN: 2222-6990 @ 2020 HRMARS

WaSRmFLVJvuxco=\&vet=10ahUKEwiiso6Sge_WAhUBQI8KHZHEArAQ9QEIKTAA..i\&docid=QfR Gk3IYD817sM\&sa=X\&ved=0ahUKEwiiso6Sge_WAhUBQI8KHZHEArAQ9QEIKTAA

McCabe, M. (2014). The meaning of the word "Shalom". Retrieved from http://www.shalomconflictc enter.org/wp.content/uploads/2014/11/SCCRR_THE_MEANING_OF_THE_WORD_SHALOM.pd $f$

McGuire, T. (2010). From emotions to spirituality: "Spiritual labor as the commodification, codification, and regulation of organizational members' spirituality. Management Communication Quarterly, 24, 74-103. Retrieved from https://www.researchgate.net/deref/ht tp\%3A\%2F\%2Fmcq.sagepub.com\%2Fcontent\%2F24\%2F1\%2F74.refs.html

McShane, S. L., \& Von, G. M. A. (2010). Organizational behavior: Emerging knowledge and practice for the real world. NY: McGraw-Hill. Retrieved from https://www.academia.edu/29097775/Mc _Shane_von_Glinow_Organizational_Behavior_ebook_Copy?auto=download

Mesquita, B., \& Ellsworth, P. C. (2001). The role of culture in appraisal. In Scherer, K.R., Schorr, A., and Johnson T. (ed.), Appraisal processes in emotion: Theory, method, research. New York: Oxford University Press. p.233-248.

Mesquita, B., Frida, N. H., \& Scherer, K. R. (1997). Culture and emotion. In Berry, J.W., Dasen, P.R., and Saraswathi, T.S. (ed.), Handbook of cross-cultural psychology: vol 2. Basic processes and human development. Boston: Allyn and Bacon. pp. 255-297.

Millennials - A portrait of generation next: Confident. Connected. Open to change. (2010). Pew Research Centre. Retrieved from http://www.pewsocialtrends.org/files/2010/10/millennialsconfident-connected-open-to-change.pdf

Montgomery, A. J., Panagopolou, E., Wildt, M., \& Meenks, E. (2006). Work-family interference, emotional labor, and burnout. Journal of Managerial Psychology, 21, 36-51. Retrieved from https://doi.org/10.1108/02683940610643206

Moore, T. W., \& Casper, W. J. (2006). An examination of proxy measures of workplace spirituality: A profile model of multidimensional constructs. Journal of Leadership and Organizational Studies, 12(4), 109-111. Retrieved from https://www.researchgate.net/profile/Wendy_Casper /publication/250961767_An_Examination_of_Proxy_Measures_of_Workplace_Spirituality_A_ Profile_Model_of_Multidimensional_Constructs/links/5573779d08ae7536374fd56e.pdf

Morris, J. A., \& Feldman, D. C. (1996). The dimensions, antecedents, and consequences of emotional labor. Academy of Management Review, 21, 986-1010. Retrieved from http://doi. org/fxbjt6

Mroczek, D. K., \& Kolarz, C. M. (1998). The effect of age on positive and negative affect: A developmental perspective on happiness. Journal of Personality and Social Psychology, 75(5), 1333-1349. Retrieved from http://citeseerx.ist.psu.edu/viewdoc/download?doi=10.1.1.436.12 39\&rep=rep $1 \&$ type $=p d f$

Mroz, J., \& Kaleta, K. (2016). Relationships between personality, emotional labor, work engagement and job satisfaction in service professions. International Journal of Occupational Medicine and Environmental Health, 29(5), 767-782. Retrieved from

http://eds.b.ebscohost.com.newdc.oum.

edu.my/eds/pdfviewer/pdfviewer?vid=2\&sid=958253c1-5596-418b-b098-ee6944d78856\%40 sessionmgr103 
INTERNATIONAL JOURNAL OF ACADEMIC RESEARCH IN BUSINESS AND SOCIAL SCIENCES

Vol. 10, No. 15, Youth and Community Wellbeing: Issues, Challenges and Opportunities for Empowerment V1. 2020, E-ISSN: 2222-6990 @) 2020 HRMARS

Naring, G., Vlerick, P., \& Van de Ven, B. (2011). Emotion work and emotional exhaustion in teachers: The job and individual perspective. Educational Studies. Retrieved from https://dspace.ou.nl/ bitstream/1820/3420/1/Repository-Emotion-work-EduStudies-Naring-Vlerick-VandeVen.pdf

Naveed, Y. (2013). Emotional labor and big five personality model. Proceedings of $3^{\text {rd }}$ Conference on Business Management. Retrieved from https://cgr.umt.edu.pk/icobm2013/papers/Papers/IC3-Sept-2012-002.pdf

O'Connor, K. E. (2008). "You choose to care": Teachers, emotions and personality identity. Teaching and Teacher Education, 24, 117-126. Retrieved from https://www.journals.elsevier.com/ teaching-and-teacher-education/virtual-special-issues/teachers-and-emotions-in-teachingand-teacher-education-tate

Ozan, M. B., \& Sener, G. [2014]. Teaching and emotional labor. American International Journal of Social Science, 3(5), 111-119. Retrieved from http://www.aijssnet.com/journals/Vol_3_No_5_ October_2014/12.pdf

Parkinson, B., Fischer, A. H., \& Manstead, A. R. (2005). Emotion in social relation: Cultural, group, and interpersonal processes. New York: Psychology Press.

Prentice, C. (2008). Trait emotional intelligence, personality and the self-perceived performance rating of casino key account representative. Victoria University. Retrieved from http://citese erx.ist.psu.edu/viewdoc/download?doi=10.1.1.600.6254\&rep=rep1\&type=pdf

Robbins, S. P. (1998). Organizational behavior ( $8^{\text {th }}$ ed.). Upper Saddle River, NJ: Prentice-Hall.

Roberts, B. W. (2009). Back to the future: Personality and assessment and personality development. Journal of Research in Personality 43(2), 137-145. Retrieved from https://www.ncbi.nlm.nih.go v/pmc/articles/PMC2711529/

Roseman, I. J., \& Smith, C. A. (2001). Appraisal theory: Overview, assumptions, varieties, controversies. In Scherer, K.R., Schorr, A., \& Johnson, T. (eds), Appraisal processes in emotion: Theory, methods, research. New York: Oxford University Press. pp. 13-19.

Saks, A. M. (2006). Antecedents and consequences of job engagement. Journal of managerial psychology, 21(7), 600-618. Retrieved from http://cinik.free.fr/chlo/doc\%20dans\%20biblio, \%20non\%20imprim\%C3\%A9s/maintien\%20dans\%20l'emploi/atcd\%20et\%20cons\%C3\%A9que nces\%20de\%20engagement.pdf

Yosef, S. (2017). Malaysia and South East Asia expand international education. In Lam, M., \& Yew, N. (eds.), Education Destination Malaysia: Guide to international and private schools. Kuala Lumpur.

Scherer, K. R., Schorr, A. \& Johnson, T. (2001). The nature and study of appraisal: A review of the issues. Appraisal processes in emotion: Theory, methods, research. New York: Oxford University Press. pp. 369-391.

Simpson, R. (2006). 'Emotional labour and identity work of men in caring roles', Proceedings of the 20th ANZAM (Australian New Zealand Academy of Management) Conference on "Management: Pragmatism, Philosophy, Priorities", 6-9 December 2006, Central Queensland University, Rockhampton. http://library-resources.cqu.edu.au:8888/access/detail.php?pid=cq u:970

Smith, H. C., \& Wakeley, J. H. (1972). Psychology of industrial behavior (3 ${ }^{\text {rd }}$ ed.). New York: McGrawHill. 
INTERNATIONAL JOURNAL OF ACADEMIC RESEARCH IN BUSINESS AND SOCIAL SCIENCES

Vol. 10, No. 15, Youth and Community Wellbeing: Issues, Challenges and Opportunities for Empowerment V1. 2020, E-ISSN: 2222-6990 @) 2020 HRMARS

Snyder, D. K., Simpson, J. A., \& Hughes, J. N. (2006) Emotion regulation in couples and families: Pathways to Dysfunction and Health. (ed.). Washington DC: American Psychological Association. Retrieved from http://docview1.tlvnimg.com/tailieu/2013/20130322/lyly_5/_ douglas_k_snyder_jeffry_a_simpson_jan_n_hugh_8898.pdf

Steinberg, R. J., \& Figart, D. M. (1999). Emotional demands at work: A job content analysis. The Annals of the American Academy of Political and Social Science, 561-577.

Sutton, R. E. (2000a). The emotional experiences of teachers. Paper presented at the annual meeting of the American Educational Research Association, New Orleans, LA. Retrieved from https://doi.org/10.1007/s11218-004-4229-y

Sutton, R. E., \& Wheatley, K. F. (2003). Teachers' emotions and teaching: A review of literature and directions for future research. Educational Psychological Review, 15(4), 327-358. Retrieved from

http://eds.a.ebscohost.com.newdc.oum.edu.my/eds/pdfviewer/pdfviewer?vid=0\&sid=65 e0e78f-c336-4a32-85f3-c965c59ecdad\%40sessionmgr4010

Taormina, R. J., \& Gao, J. H. (2010). A research model for guanxi behavior: Antecedents, measures, and outcomes of Chinese social networking. Social Science Research, 39, 1195-1212. Retrieved from http://doi.org.dfwj63

Taylor, P. J., Russ-Eft, D. F., \& Chan, D. W. L. (2005). A meta-analytic review of behavior modeling training. Journal of Applied Psychology, 90(4), 692-709. Retrieved from https://pdfs.semantic scholar.org/ee8c/1fb314607e47cda6369ea6e65ad67a947069.pdf

Tice, D. M., Bratslavsky, E., \& Baumeister, R. F. (2001). Emotional distress regulation takes precedence over impulse control: If you feel bad, do it! Journal of Personality and Social Psychology, 80(1), 53-67. Retrieved from https://pdfs.semanticscholar.org/26e9/c66997ce5a9 75a09141a21078c0f7aaaab39.pdf

Tickle, L. (1991). New teachers and the emotions of learning teaching. Cambridge Journal of Education, 21, 319-329. Retrieved from http://dx.doi.org/10.1080/0305764910210306

Tokar, D. M., Fisher, A. R., \& Subich, L. M. (1998). Personality and vocational behavior: A selective review of the literature, 1993-1997. Journal of Vocational Behavior, 53, 115-153.

Tolich, M. B. (1993). Alienating and liberating emotions at work: Supermarket clerks' performance of customer service. Journal of Contemporary Ethnography, 22(30), 361-381. Retrieved from http: //doi:10.1177/089124193022003004.

Toremen, F., \& Cankaya, I. (2008). An effective approach at management: Emotional management. Kuramsal Egitimbilim, 1, 33-47.

Totterdell, P., \& Parkinson, B. (1999). Use and effectiveness of self-regulation strategies for improving mood in a group of trainee teachers. Journal of Occupational Health Psychology, 4, 219-232. Retrieved from http://dx.doi.org/10.1037/1076-8998.4.3.219

Tsang, K. K. [2011]. Emotional labor of teaching. International Research Journals: Educational Research, 2(8), 1312-1316. Retrieved from http://www.interesjournals.org/fullarticles/emotio nal-labor-of teaching.pdf?view=inline.

Turner, A. N., \& Lawrence, P. R. (1965). Industrial jobs and the worker: An investigation of response to task attributes. Boston: MA: Harvard University, Division of Research, Graduate School of Business Administration. Retrieved from http://trove.nla.gov.au/version/15407166 
INTERNATIONAL JOURNAL OF ACADEMIC RESEARCH IN BUSINESS AND SOCIAL SCIENCES

Vol. 10, No. 15, Youth and Community Wellbeing: Issues, Challenges and Opportunities for Empowerment V1. 2020, E-ISSN: 2222-6990 @ 2020 HRMARS

Turner, J. H., \& Stets, J. E. (2006). Sociological theories of human emotions. Annual Review of Sociology, 35, 25-52. Retrieved from http://www.annualreviews.org/doi/abs/10.1146/annurev .soc.32.061604.123130

Underwood, L. G., \& Teresi, J. (2002). The daily spiritual experience scale: Development, theoretical description, reliability, exploratory factor analysis, and preliminary construct validity using health related data. Religions 2011, 2(1), 29-50. Retrieved from doi:10.3390/rel2010029

Nel, P. J. (1996). "salom". New International Dictionary of Old Testament Theology and Exegesis. Vol. 4. (ed.) Cumbria, UK: Paternoster Press, 130-134.

Wiggins, J., S., \& Trapnell, P., D. (1997). Personality Structure: The return of the big five.

Winograd, K. (2003). The functions of teacher emotion: The good, the bad, and the ugly. Teachers College Record, 105(9), 1641-1673.

Wolpow, R., Johnson, M. M., Hertel, R., \& Kincaid, S., O. (2016). The heart of teaching and learning: Compassion, Resiliency, and academic success. $3^{\text {rd }}$ printing. Washington State Office of Superintendent of Public Instruction (OSPI) Compassionate Schools. Retrieved from http://ww w.k12.wa.us/compassionateschools/pubdocs/TheHeartofLearningandTeaching.pdf

Wright, B., E., \& Davis, B., S. (2003). Job satisfaction in public sector: The role of the work environment. The American Review of Public Administration, 33, 77-90. Retrieved from http:// doi.org/bdbvp4

Ye, M., L., \& Chen, Y. (2015). A literature review on teachers' emotional labor. Creative Education, 6, 2232-2240. Retrieved from https://file.scirp.org/pdf/CE_2015113017181739.pdf

Yin, H., B., \& Lee, J., C., K. (2012). Be Passionate, But Be Rational as Well: Emotional Rules for Chinese Teachers' Work. Teaching and Teacher Education, 28, 56-65. http://dx.doi.org/10.1016/j.tate. 2011.08.005

Yuu, K. (2010). Expressing emotions in teaching: Inducement, suppression, and disclosure as caring profession. Educational Studies in Japan: International Yearbook, 5, 63-78. Retrieved from http ://citeseerx.ist.psu.edu/viewdoc/download?doi=10.1.1.878.634\&rep=rep1\&type=pdf

Zapf, D. C., Vogt, C., Seifert, H., Mertini, \& Isic, A. (1999). Emotion work as a source of stress: The concept and the development of an instrument. European Journal of Work and Organizational Psychology, 8, 371-400. Retrieved from https://www.google.com/url?sa=t\&rct=j\&q=\&esrc=s\& source $=$ web $\& c d=2 \& c a d=r j a \& u a c t=8 \& v e d=0$ ahUKEwjGkZqz3bbXAhWLerwKHRlaBMEQFggvMA E\&url=https\%3A\%2F\%2Fwww.slideshare.net\%2FSolercanto\%2Fvol-

8\&usg=AOvVaw3243X7SdOk 3p10h2JTnV4f

Zapf, D. (2002). Emotion work and psychological well-being: A review of the literature and some conceptual considerations. Human Resource Management Review, 12, 237-268. DOI: http://doi.org/gt3

Zembylas, M. (2002). Structures of feeling in curriculum and teaching: Theorizing the emotional rules. Educational Theory, 52(2), 187-208. Retrieved from DOI: http:// doi:10.1111/j.1741-5446 .2002.00187.x

Zembylas, M. (2004). Emotion metaphors and emotional labor in science teaching. Science Education, 88(3), 301-324. Retrieved from http://doi.10.1002/sce.10116

Zembylas, M. (2005). Discursive practices, genealogies, and emotional rules: A poststructuralist view on emotion and identity in teaching. Teaching and Teacher Education, 21(8), 935-948. Retrieved from DOI: http://doi:10.1016/j.tate.2005.06.005 
Vol. 10, No. 15, Youth and Community Wellbeing: Issues, Challenges and Opportunities for Empowerment V1. 2020, E-ISSN: 2222-6990 @ 2020 HRMARS

Zhai, Q., Lindorff, M., \& Cooper, B. (2013). Workplace guanxi: Its dispositional antecedents and mediating role in the affectivity-job satisfaction relationship. Journal of Business Ethics 117, 541-551. Retrieved from DOI: http://doi.org/2gf 